Research Article

\title{
Feedback of second-year medical students' towards teaching/learning of pharmacology in a private medical college of India
}

\author{
Sameer Uz Zaman*, Ravindra S. Beedimani, A. Naga Teja Pavani, K. Santosh Kumar
}

\begin{abstract}
Department of Pharmacology, Kamineni Academy of Medical Sciences and Research Centre (KAMSRC), Hyderabad, Telangana, India

Received: 13 July 2016

Revised: 15 July 2016

Accepted: 13 August 2016

*Correspondence to:

Dr. Sameer Uz Zaman,

Email: samsparkin@gmail.com

Copyright: (C) the author(s), publisher and licensee Medip Academy. This is an openaccess article distributed under the terms of the Creative Commons Attribution NonCommercial License, which permits unrestricted noncommercial use, distribution, and reproduction in any medium, provided the original work is properly cited.
\end{abstract}

\begin{abstract}
Background: In order to ensure a successful and sustainable curriculum, regular feedback from students about their views of teaching and learning experience is a must. The purpose of this study was to assess whether course content and teaching-learning aids are actually supporting the curriculum goals and what reforms can be implemented for the betterment of teaching pharmacology for medical students.

Methods: After Institutional Review Board approval (IRB), a total of 120 second-year medical students of the Kamineni Academy of Medical Sciences and Research Centre (KAMSRC), L.B Nagar, Hyderabad, Telangana were interviewed with a structured questionnaire. Descriptive statistics were used for analysis of data and the results were expressed as percentage $(\%)$.

Results: Pharmacology was considered a useful subject by $51 \%$ of second-yearMBBS students. They found cardiovascular system (34\%) followed by chemotherapy $(21 \%)$ as the most interesting topics. $25 \%$ students liked didactic lectures followed by MCQs (19\%). A whopping 50\% suggested the lectures should be clinically-oriented. 35\% students studied from a combination of lecture notes and text books. According to them, the pharmacology teacher should be knowledgeable and student-friendly. About $77 \%$ students think that pharmacology teachers have those qualities.

Conclusions: This study revealed that the medical students wish to learn pharmacology from both theoretical and practical approaches. There is a need to incorporate more clinically-oriented exercises like case studies and clinical vignette containing multiple choice questions (MCQs) to better equip the students toward clinical therapeutics. It is therefore imperative to adapt the curriculum of pharmacology in line with the present trend.
\end{abstract}

Keywords: Feedback, Second-year MBBS students, Pharmacology, Teaching, Learning

\section{INTRODUCTION}

There is a growing awareness that learners' views of their educational experiences are valuable in assessing the effectiveness of course content and teaching methods. Student feedback is a critical component of the teacherlearner cycle. ${ }^{1}$ In many medical colleges, instruction of students in pharmacology remains formal and may be inadequate. Pharmacology is one of the most important subjects that form the backbone of rational therapeutics. The primary objective of teaching-learning pharmacology is to enable medical students to take rational therapeutic decisions in clinical practice. ${ }^{2}$ Pharmacology is often perceived as dry and volatile by most second-year MBBS students. Due to content overload, students also find it difficult to remember and recall pharmacological terms, concepts and drug names in the subject. Many attempts have been made by various colleges all over India and abroad to make the teaching-learning of pharmacology more interesting and relevant. ${ }^{3}$ It is generally agreed that reviewing the teaching program at regular intervals and modifications in the content and methodologies of imparting basic knowledge about drugs and drug therapies is a must. ${ }^{4}$ Questionnaires offer an objective means of collecting information about the student's attitude, belief, behaviour and knowledge. However, questionnaires should be validated, reliable and standardized. Understanding current perceptions held by future medical practitioners regarding pharmacology for its role in application of basic concepts to clinical practice may be helpful for introducing appropriate changes into the curricula where and when necessary. 


\section{METHODS}

This was a cross-sectional study based on the structured questionnaire carried out by the Department of Pharmacology at Kamineni Academy of Medical Sciences and Research Centre (KAMSRC), Hyderabad, Telangana in January, 2016. After getting the protocol approved by Institutional Review Board (IRB), a total of 120 second-year medical students of KAMSRC, L.B Nagar, Hyderabad who were due to appear for secondyear M.B.B.S degree examinations in February, 2016 were interviewed with a structured questionnaire. The questionnaire was adapted from the previous studies that assessed feedback of second-year MBBS students on teaching-learning methodology in pharmacology. $5,6 \mathrm{~A}$ few modifications were done to the questionnaire to best fit the university syllabus. The questionnaire contained a total of 19 questions under two main categories, general questions and teaching/learning methodology in pharmacology course. Some of the questions were closeended but the ones related to suggestion on teachinglearning of pharmacology were open-ended. The questionnaire validation was done by a pilot study on 15 students. Each question had 3 to 7 options and they were asked to mark the single best option. The questionnaire is provided in Appendix 1. Students were instructed not to reveal their identity in the questionnaire. At the end of the questionnaire, space was provided for suggestions and remarks. About thirty minutes was provided for answering the questionnaire.

\section{RESULTS}

Out of the 120 students who were administered questionnaires, 100 completed questionnaires were accepted giving a response rate of $83.33 \%$. Some of the students did not attempt a few questions or ticked multiple options and when such discrepancies were found for more than three questions, the questionnaire was discarded. Descriptive statistics was used for analysis of data and results were expressed as a percentage. Pearson Chi square test was used to compare the responses to various questions. $\mathrm{P}<0.05$ was considered as significant. The detailed response of the students to the questionnaire on teaching-learning methods in pharmacology is depicted in Table 1 and Table 2.

$51 \%$ students considered pharmacology as interesting and useful; $17 \%$ as boring but useful; $27 \%$ as interesting but cramming and $1 \%$ useless and cramming $34 \%$ found cardiovascular system (CVS/ANS), 21\% chemotherapy, $11 \%$ central nervous system (CNS) and $11 \%$ general pharmacology as most interesting sections of pharmacology.

$25 \%$ considered didactic lectures, 19\% MCQs and 17\% clinical pharmacology problems as most interesting teaching-learning methods. $43 \%$ students suggested introducing more group discussions and $37 \%$ favoured to include more MCQs as reforms to be made.
$50 \%$ admitted that regular pharmacology lectures should be more clinical oriented and 25\% suggested MCQs to be added to regular pharmacology lectures.

When questioned about their preferred method of studying pharmacology, it was noted that $37 \%$ of students preferred textbooks only followed by $35 \%$ students who relied on a combination of textbooks and lecture notes. $16 \%$ of students admitted to using self-prepared notes made after referring lecture notes and text books.

$45 \%$ of the students admitted that they studied the subject regularly, out of which $24 \%$ stated that they studied only because of regular tests and viva, $11 \%$ to gain knowledge and only $10 \%$ because of interest in the subject. $47 \%$ of the students stated that they studied only during tests and examinations; while $8 \%$ students said they would study only for the university examinations.

About $57 \%$ of students are interested in studying drugs used in all special populations like pregnancy, paediatrics and geriatrics and liver/kidney dysfunction. However, $17 \%$ of students were interested in topics like drugs in pregnancy and $13 \%$ of students interested in discussion of drugs in liver/kidney dysfunction.

\section{DISCUSSION}

In the present study, many interesting facts were noticed and students suggested many things that could be incorporated into conventional pharmacology teaching so as to make the subject more interesting and comprehensive. Although majority of the entrant students had some knowledge about pharmacology, there was a group who were totally unaware of the subject; hence, there is a need to conduct a subject orientation programme before the students enter into medical education. Majority of the students found cardiovascular system, chemotherapy, central nervous system and general pharmacology as the most interesting topics in pharmacology, where endocrine system, gastrointestinal system, autacoids and respiratory system were regarded as less interesting topics. These topics need to be made more interesting and emphasized upon to draw the attention of the students. This could be done by utilizing their suggestions like use of MCQs, tutoring sessions, clinical pharmacology sessions, and case studies. Use of computer aided learning software like animal simulator could be a novel method during practical sessions for a better understanding of the autonomic nervous system. Many students do not seem to be interested in prescription writing as well. Several studies mentioned about the inability of junior doctors in rational prescription. ${ }^{7}$ It would be a good idea to include a few clinical pharmacology sessions dedicated to strengthen rational prescription writing. Most of the students study from textbooks and do not seem to be attentive in the lectures. Students even commented that they do not get much from the pharmacology lectures. 
Table 1: MBBS Students responses to questions (1-10) on teaching-learning methods in pharmacology.

\begin{tabular}{|c|c|c|c|c|}
\hline \multicolumn{5}{|c|}{ Students response to questionnaire in percentage $(\%)$} \\
\hline $\begin{array}{l}\text { 1. Did you know about pharmacology } \\
\text { before it was introduced to you in II } \\
\text { MBBS? }\end{array}$ & No $20 \%$ & Somewhat $71 \%$ & \multicolumn{2}{|c|}{ Yes, many things $9 \%$} \\
\hline $\begin{array}{l}\text { 2. What is your opinion about } \\
\text { pharmacology? }\end{array}$ & $\begin{array}{l}\text { Useful but } \\
\text { boring } 17 \%\end{array}$ & $\begin{array}{l}\text { Useful and } \\
\text { interesting } 51 \%\end{array}$ & $\begin{array}{l}\text { Useless and } \\
\text { cramming } 1 \%\end{array}$ & $\begin{array}{l}\text { Interesting but } \\
\text { cramming } 27 \%\end{array}$ \\
\hline \multirow{2}{*}{$\begin{array}{l}\text { 3. Which topics did you find interesting in } \\
\text { pharmacology? }\end{array}$} & General $11 \%$ & CVS/ ANS 34\% & $\begin{array}{l}\text { Chemotherapy } \\
21 \%\end{array}$ & Endocrine $7 \%$ \\
\hline & CNS $11 \%$ & Respiratory 3\% & Autacoids $0 \%$ & \\
\hline \multirow{2}{*}{$\begin{array}{l}\text { 4. Which of the following type of } \\
\text { teaching-learning method was most } \\
\text { interesting? }\end{array}$} & Lectures $25 \%$ & $\begin{array}{l}\text { Prescription } \\
\text { writing } 10 \%\end{array}$ & $\begin{array}{l}\text { Clinical } \\
\text { Pharmacology } \\
\text { Problems } 17 \%\end{array}$ & MCQs $19 \%$ \\
\hline & $\begin{array}{l}\text { Animal } \\
\text { Simulator } 6 \%\end{array}$ & Tutorials $15 \%$ & $\begin{array}{l}\text { Students' } \\
\text { Seminars } 8 \%\end{array}$ & Practicals $0 \%$ \\
\hline \multirow[t]{2}{*}{$\begin{array}{l}\text { 5. Would you like any of the following } \\
\text { reforms to be made? }\end{array}$} & $\begin{array}{l}\text { Decrease the } \\
\text { number of } \\
\text { lectures } 0 \%\end{array}$ & $\begin{array}{l}\text { Increase the } \\
\text { number of } \\
\text { lectures } 10 \%\end{array}$ & $\begin{array}{l}\text { Introduce Group } \\
\text { Discussions } 43 \%\end{array}$ & $\begin{array}{l}\text { Include more } \\
\text { MCQs } 37 \%\end{array}$ \\
\hline & \multicolumn{4}{|c|}{ Include more student seminars $6 \%$} \\
\hline $\begin{array}{l}\text { 6. Would you like any of the following to } \\
\text { be added as a part of regular teaching in } \\
\text { pharmacology? }\end{array}$ & $\begin{array}{l}\text { Student } \\
\text { Seminars 3\% }\end{array}$ & $\begin{array}{l}\text { Clinically } \\
\text { oriented lectures/ } \\
\text { Case studies } \\
50 \%\end{array}$ & $\begin{array}{l}\text { Group } \\
\text { discussions } 22 \%\end{array}$ & MCQs $25 \%$ \\
\hline \multirow{2}{*}{$\begin{array}{l}\text { 7. From where did you prefer studying } \\
\text { pharmacology? }\end{array}$} & $\begin{array}{l}\text { Lecture notes } \\
\text { only } 0 \%\end{array}$ & $\begin{array}{l}\text { Text books only } \\
37 \%\end{array}$ & $\begin{array}{l}\text { Lecture notes } \\
\text { and text books } \\
\text { combined } 35 \%\end{array}$ & $\begin{array}{l}\text { Lecture notes } \\
\text { of certain staff } \\
\text { members only } \\
8 \%\end{array}$ \\
\hline & \multicolumn{2}{|c|}{$\begin{array}{l}\text { Lecture notes of certain topics, } \\
\text { irrespective of staff member } 4 \%\end{array}$} & \multicolumn{2}{|c|}{$\begin{array}{l}\text { Own notes after referring lecture } \\
\text { notes, text books } 16 \%\end{array}$} \\
\hline $\begin{array}{l}\text { 8. What is your pattern of study in } \\
\text { pharmacology? }\end{array}$ & $\begin{array}{l}\text { Regular } \\
\text { because of } \\
\text { interest/tests/ } \\
\text { viva/ tutorials } \\
45 \%\end{array}$ & $\begin{array}{l}\text { Study only for } \\
\text { final exams. } \\
8 \%\end{array}$ & $\begin{array}{l}\text { Only during } \\
\text { tutorials/ tests / } \\
\text { exams } 47 \%\end{array}$ & \\
\hline 9. How is your grasping power? & Good $57 \%$ & $\begin{array}{l}\text { Cramming helps } \\
39 \%\end{array}$ & $\begin{array}{l}\text { Can never learn. } \\
4 \%\end{array}$ & \\
\hline \multirow{2}{*}{$\begin{array}{l}\text { 10. Do you think the following special } \\
\text { topics should be discussed in lectures / } \\
\text { practicals? }\end{array}$} & $\begin{array}{l}\text { Pediatric } \\
\text { Pharmacology } \\
9 \%\end{array}$ & $\begin{array}{l}\text { Geriatric } \\
\text { Pharmacology } \\
3 \%\end{array}$ & $\begin{array}{l}\text { Drugs in } \\
\text { Pregnancy } 17 \%\end{array}$ & $\begin{array}{l}\text { Drugs used in } \\
\text { sexual function } \\
1 \%\end{array}$ \\
\hline & $\begin{array}{l}\text { Drugs in } \\
\text { liver/kidney } \\
\text { dysfunction } \\
13 \%\end{array}$ & $\begin{array}{l}\text { All of the above } \\
57 \%\end{array}$ & & \\
\hline
\end{tabular}

Comparison of students responses as percentage (\%) of the total participants ( $N=100$ students)

It is the responsibility of the teaching faculty to take a note of this and work on it. They suggested that teachers should not just read the slides and should come up with a good presentation with clarity in concepts. These are the qualities of good pharmacology teachers according to them. There are a significant proportion of students who consider themselves as having good grasping power but admit that they just memorize or cram in pharmacology. Time and efforts should also be focused on discussion of the pathophysiological concepts and basis of drug therapy rather than rote memorization. This is especially important in general pharmacology and autonomic pharmacology for long-term retention. ${ }^{8}$ Significant improvement is required in this direction for pharmacology teachers through discussion and seeking guidance from the medical education committee. As a great majority of students suggested presenting the pharmacology lectures in a more clinical-oriented format, there should be inclusion of clinical case studies, clinical pharmacology sessions and clinical vignette containing MCQs which are interesting, relevant and helpful for better comprehension rather than the old conventional 
format of mechanism of action, adverse effects and uses. $^{8,9}$ Although not always feasible, few MCQs may be provided as home assignment and discussed during revision classes. Students seem also to be interested in special topics like drugs in pregnancy and drugs used in liver and kidney disease etc. It is better to have few lectures on these topics. A few lectures on drug therapy and new drugs can also be conducted in the third year of MBBS as suggested by many students. This will help them not only to revise but also learn about recent advances made in a particular field. A majority of students stated that they are afraid of teachers and do not consider them to be student friendly. They expected teachers to be student-friendly for better interaction during tutorials and also to approach them for questions after lectures. Interaction with students' in a more cordial way during tutorials and practical classes may enhance the learning environment and thereby improve student participation. This approach towards teaching pharmacology would be the best way to break the barrier between the student and teachers and thus improve interaction. A variety of novel learning formats like problem-based learning sessions, small group case discussions, peer-teaching, quizzes, and podcasts can be used to teach students how to apply the general concepts of clinical pharmacology and rational pharmacotherapy to clinical medicine, and to prepare them to promote safe use of drugs in therapeutics. ${ }^{10,11}$ Many studies have suggested that restructuring the pharmacology curriculum with inclusion of small group case-based learning led to a significant improvement of self-reported student satisfaction, motivation, and engagement. ${ }^{12}$

Table 2: MBBS Students responses to questions (11-19) on teaching-learning methods in pharmacology.

\begin{tabular}{|c|c|c|c|c|}
\hline \multicolumn{5}{|l|}{ Students response to questionnaire in percentage (\%) } \\
\hline \multirow[t]{2}{*}{ 11. How do you rate pharmacology lectures? } & $\begin{array}{l}\text { Always boring } \\
0 \%\end{array}$ & $\begin{array}{l}\text { Some } \\
\text { interesting, } \\
\text { some boring } \\
45 \%\end{array}$ & $\begin{array}{l}\text { Always } \\
\text { interesting } \\
7 \%\end{array}$ & $\begin{array}{l}\text { Most } \\
\text { interesting, } \\
\text { some boring } \\
41 \%\end{array}$ \\
\hline & \multicolumn{4}{|c|}{ Most boring, few interesting $7 \%$} \\
\hline $\begin{array}{l}\text { 12. How do you rate pharmacology in comparison } \\
\text { to other II MBBS subjects? }\end{array}$ & $\begin{array}{l}\text { Useless, not } \\
\text { important } 0 \%\end{array}$ & $\begin{array}{l}\text { At par with } \\
\text { others } 31 \%\end{array}$ & \multicolumn{2}{|c|}{$\begin{array}{l}\text { Above others in all respects } \\
69 \%\end{array}$} \\
\hline \multirow[t]{2}{*}{ 13. How do you rate it overall? } & $\begin{array}{l}\text { Useless } \\
\text { altogether } 0 \%\end{array}$ & $\begin{array}{l}\text { Only } \\
\text { theoretical, less } \\
\text { practical use } \\
3 \%\end{array}$ & At par $27 \%$ & $\begin{array}{l}\text { One of the } \\
\text { few most } \\
\text { important } \\
40 \%\end{array}$ \\
\hline & \multicolumn{4}{|c|}{$\begin{array}{l}\text { Most important, above all subjects } \\
30 \%\end{array}$} \\
\hline $\begin{array}{l}\text { 14. Do you think the pharmacology should be } \\
\text { taught in or after III MBBS? }\end{array}$ & $\begin{array}{l}\text { A few lectures } \\
\text { on drug } \\
\text { therapy in III } \\
\text { MBBS } 61 \%\end{array}$ & $\begin{array}{l}\text { Enough of } \\
\text { pharmacology } \\
20 \%\end{array}$ & $\begin{array}{l}\text { Orientation } \\
\text { course of } \\
\text { few days } \\
\text { during } \\
\text { Internship } \\
17 \%\end{array}$ & $\begin{array}{l}\text { The subject } \\
\text { should be } \\
\text { taught in } \\
\text { entire III } \\
\text { year } 2 \%\end{array}$ \\
\hline $\begin{array}{l}\text { 15. Do you think it should carry more weight in } \\
\text { examinations? }\end{array}$ & $\begin{array}{l}\text { Yes, more } \\
\text { marks than } \\
\text { others } 13 \%\end{array}$ & $\begin{array}{l}\text { The present } \\
\text { pattern is okay } \\
85 \%\end{array}$ & \multicolumn{2}{|c|}{ Less marks than others. $2 \%$} \\
\hline \multirow[t]{2}{*}{$\begin{array}{l}\text { 16. What according to you should be the qualities } \\
\text { of a good pharmacology teacher? }\end{array}$} & $\begin{array}{l}\text { Make subject } \\
\text { interesting } 18 \%\end{array}$ & $\begin{array}{l}\text { Student } \\
\text { friendly } 15 \%\end{array}$ & $\begin{array}{l}\text { Clinical- } \\
\text { oriented } 13 \%\end{array}$ & $\begin{array}{l}\text { Knowledge } \\
\text { and logical } \\
7 \%\end{array}$ \\
\hline & Interactive $6 \%$ & $\begin{array}{l}\text { Shouldn't read } \\
\text { slides } 5 \%\end{array}$ & \multicolumn{2}{|c|}{$\begin{array}{l}\text { More practical } \\
4 \%\end{array}$} \\
\hline $\begin{array}{l}\text { 17. Do you think your pharmacology teachers } \\
\text { have the above qualities? }\end{array}$ & \multicolumn{2}{|l|}{ Yes $90 \%$} & \multicolumn{2}{|l|}{ No $1 \%$} \\
\hline $\begin{array}{l}\text { 18. Do you think pharmacologists are respected as } \\
\text { expert physician? }\end{array}$ & No $8 \%$ & Yes $44 \%$ & $\begin{array}{l}\text { Ought to } \\
\text { have } 31\end{array}$ & $\begin{array}{l}\text { Do not know } \\
17 \%\end{array}$ \\
\hline $\begin{array}{l}\text { 19. Do you think it is necessary to have tutorials } \\
\text { in pharmacology? }\end{array}$ & \multicolumn{2}{|l|}{ No $12 \%$} & \multicolumn{2}{|l|}{ Yes $88 \%$} \\
\hline
\end{tabular}

Comparison of students responses as percentage (\%) of the total participants ( $N=100$ students) 
This study had certain limitations as it was conducted in 120 students who consented to participate and only 100 were accepted in total, which may not be a sizeable cohort to uncover all the differences. In addition, questionnaires were only validated for content by local experts and not externally validated.

In light of the results of the present study, we should understand that all these issues must be taken into consideration while updating the medical curriculum and teaching schedule. Involvement of students improves learning, and thereby enhances performance in university examinations.

\section{CONCLUSION}

The students' feedback provides important information about the need for modification of the medical pharmacology curriculum so as to make it more interesting and clinically relevant. Teaching and learning is a dynamic process and depending on the subject it can be accomplished by various ways and means. Curriculum evaluation is the key to continuous assurance of quality of education. One single approach to teaching does not work for every student or for even most of the students. The educators' awareness of the various learning styles of the students and their efforts towards matching the students' aspirations may help in creating an effective learning environment for all the students. Students are usually regarded as the best judges to evaluate the effectiveness of teaching content and methods.

Funding: No funding sources

Conflict of interest: None declared

Ethical approval: The study was approved by the Institutional Ethics Committee

\section{REFERENCES}

1. Colbert-Getz JM, Baumann S. Changing medical students' perception of the evaluation culture: Is it possible? J Educ Eval Health Prof. 2016;13:8.

2. Gwee MC. Teaching of medical pharmacology: the need to nurture the early development of desired attitudes for safe and rational drug prescribing. Med Teach. 2009;31(9):847-54.
3. Achike FI, Ogle CW. Information overload in the teaching of pharmacology. J Clin Pharmacol. 2000;40(2):177-83.

4. Galukande M, Katamba A, Kiguli S, KiguliMalwadde E, Kijjambu S, Sewankambo N. Problem based learning: tutors' views 5 years after implementation at a sub-Saharan University. Afr Health Sci. 2015;15(1):261-8.

5. Bhosale UA, Yegnanarayan R, Yadav GE. Attitude, perception and feedback of second year medical students on teaching-learning methodology and evaluation methods in pharmacology: A questionnaire-based study. Niger Med J. 2013;54(1):33-9.

6. Oshikoya KA. Teaching undergraduate MBBS pharmacology in Nigeria: a need for curriculum modification. West Afr J Med. 2007;26(3):256.

7. O'Shaughnessy L, Haq I, Maxwell S, Llewelyn M. Teaching of clinical pharmacology and therapeutics in UK medical schools: current status in 2009. Br J Clin Pharmacol. 2010;70(1):143-8.

8. Sim SM. Teaching of pharmacology in Universiti Malaya and the other medical schools in Malaysia -a historical perspective. Acta Pharmacol Sin. 2004;25(9):1209-19.

9. Shenfield GM. Integrating clinical pharmacology teaching with general practice. Br J Clin Pharmacol. 1998;45(4):399-401.

10. Meade O, Bowskill D, Lymn JS. Pharmacology podcasts: a qualitative study of non-medical prescribing students' use, perceptions and impact on learning. BMC Med Educ. 2011;11:2.

11. Tofovic SP, Branch RA, Jackson EK, Cressman MD, Kost CK. Teaching clinical pharmacology and therapeutics: selective for fourth-year medical students. J Clin Pharmacol. 1998;38(8):670-9.

12. Tayem YI. The Impact of Small Group Case-based Learning on Traditional Pharmacology Teaching. Sultan Qaboos Univ Med J. 2013;13(1):115-20.

Cite this article as: Zaman SU, Beedimani RS, Pavani ANT, Kumar KS. Feedback of second-year medical students' towards teaching/learning of pharmacology in a private medical college of India. Int J Basic Clin Pharmacol 2016;5:2086-93. 


\section{Appendix 1}

1. Did you know about Pharmacology before it was introduced to you in II MBBS?

a) No

b) Somewhat

c) Yes, many things

2. What is your opinion about Pharmacology?

a) Useful but boring

b) Useful and interesting

c) Useless and cramming

d) Interesting but cramming

3. Which topics did you find interesting in Pharmacology?

a) General Pharmacology f) Respiratory System

b) Cardiovascular / ANS g) GIT

c) Chemotherapy h) Autacoids

d) Endocrine System i) Specify:

e) Central Nervous System

4. Which of the following teaching/learning method was most interesting?

a) Lectures e) Multiple choice questions (MCQs)

b) Prescription writing f) Animal Simulator

c) Tutorials g) Students' Seminars

d) Clinical Pharmacology Problems h) Practical

5. Would you like any of the following reforms to be made?

a) Decrease the number of lectures d) Include more MCQs

b) Increase the number of lectures e) Introduce Group Discussions

c) Include more Student seminars f) Specify:

6. Would you like any of the following to be added as a part of regular teaching in pharmacology?

a) Student Seminars

b) Group discussions

c) MCQs 
d) Clinically oriented lectures/Case Studies

7. From where did you prefer studying Pharmacology?

a) Lecture notes only

b) Text books only

c) Lecture notes and text books combined

d) Lecture notes of certain staff members only, irrespective of topics taken

e) Lecture notes of certain topics, irrespective of staff member

f) Own notes after referring lecture notes, text books, seniors' notes, etc.

8. What is your pattern of study in Pharmacology?

a) Regular because of interest/tests/ viva/ tutorials

b) Study only for final exams.

c) Only during tutorials/ tests / exams

9. How is your grasping power?

a) Good

b) Cramming (memorization) helps

c) Can never learn.

10. Do you think the following special topics should be discussed in lectures / practicals?

a) Pediatric Pharmacology d) Drugs used in sexual function (Yes/No)

b) Geriatric Pharmacology e) Drugs in liver/kidney dysfunction (Yes/No)

c) Drugs in Pregnancy f) All

11. How do you rate Pharmacology lectures?

a) Always boring d) Most interesting, some boring

b) Some interesting, some boring e) Most boring, few interesting.

c) Always interesting

12. How do you rate Pharmacology in comparison to other II MBBS subjects?

a) Useless, not important

b) At par with others

c) Above others in all respects

13. How do you rate it overall?

a) Useless altogether d) One of the few most important 
b) Only theoretical, less practical use e) Most important, above all subjects

c) At par

14. Do you think the subject should be taught in or after III MBBS?

a) A few lectures on drug therapy in III MBBS

b) Enough of Pharmacology

c) Orientation course of few days during Internship

d) The subject should be taught in entire III year

15. Do you think it should carry more weight in examinations?

a) Yes, more marks than others

b) The present pattern is okay

c) Less marks than others.

16. What according to you should be the qualities of a good Pharmacology teacher?

Please comment

17. Do you think your Pharmacology teachers have the above qualities?

a). Yes

b). No

18. Do you think Pharmacologists are respected as expert physician?

a) No c) Ought to have

b) Yes d) Do not know

19. Do you think it is necessary to have tutorials in Pharmacology?

a) Yes

b) No 